IRA-International Journal of Management \& Social Sciences

ISSN 2455-2267; Vol.04, Issue 01 (2016)

Institute of Research Advances

http://research-advances.org/index.php/RAJMSS

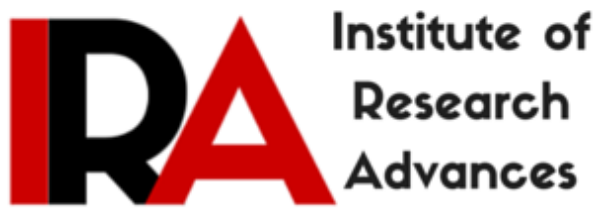

\title{
Comparative Risk Return Analysis of Bombay Stock Market with Selected Banking Stocks in India
}

\author{
Dr. Pramod Kumar Patjoshi \\ School of Management \\ Centurion University of Technology and Management \\ Bhubaneswar, Odisha, India.
}

DOI: http://dx.doi.org/10.21013/jmss.v4.n1.p18

\section{How to cite this paper:}

Patjoshi, P. (2016). Comparative Risk Return Analysis of Bombay Stock Market with Selected Banking Stocks in India. IRA-International Journal of Management \& Social Sciences (ISSN 2455-2267), 4(1).doi:http://dx.doi.org/10.21013/jmss.v4.n1.p18

(C) Institute of Research Advances

(c) ) EY-NC

This work is licensed under a Creative Commons Attribution-Non Commercial 4.0 International License subject to proper citation to the publication source of the work.

Disclaimer: The scholarly papers as reviewed and published by the Institute of Research Advances (IRA) are the views and opinions of their respective authors and are not the views or opinions of the IRA. The IRA disclaims of any harm or loss caused due to the published content to any party. 


\section{ABSTRACT}

The stock markets in India are contributing an enormous extent in progress of the economy. The banking sector engages major share among other sectors in Indian stock trading scenario. The study examines the correlation between risk and return of the Sensex and banking stocks of BSE 30 (Sensex). India's one of the superior stock exchange i.e. Bombay Stock Exchange (BSE). In this study different Sensex and banking stock indices have been used to examine the risk return trade off of Sensex with that of HDFC Bank, ICICI Bank, Axis Bank and SBI. The study is based on secondary data. The data for the analysis has taken from the BSE website over a period of 15 years from January 1, 2001 to December 31, 2015. In this analysis for testing the presence or absence of risk return trade off in the Indian equity markets and for testing hypothesis, different methods like correlation, regression, descriptive statistics and t test have been employed.

Key words: BSE, Banking Stock, Return, Stock market, risk

\section{INTRODUCTION}

In the age of growing Liberalization, Privatization and globalization in the emerging economies, stocks markets play an important part and it turn as indicator reflecting the performance of the country's economic condition. Stock market is a place where buying and selling of financial securities use to take place. It is mainly due to a high degree of volatility; prices fluctuate within minutes and are determined by the demand and supply of stocks in a given time. The buyers and sellers trade on different financial securities in the stock market, which encounter to accomplish their financial objectives from their investments. Investments in stock market involve future uncertainties, which is the risk has to tolerate by all the investors for the expected returns. Therefore investments in stock market comprise both risk as well asreturns. Theinvestors have a lodgedconcerned in the stock market to accomplish higher returns. In the contemporarysituation, researches also are compellingextremenoticeon stock market by using efficientprocedures, which in turn will be advantageous for investors over their market analysis.

Stock market in Indian has two main stock markets specifically, Bombay stock Exchange (BSE) and National Stock Exchange (NSE). Indian Stock market has seen a foremostalterationafterward the employment of liberalization, where the free flow of information' were the foremostfactors on different stock market indices. India is a developing economy; it has eyewitnessanextremealteration in the financial market (both capital market as well asmoney market) in last two decades. FIIs have also taken aacute interest in Indian stock market, consequence India prosperous enough to acquire a major segment from foreign investors inrecent period. This has likewise increased the risk connectedinvestment in financial securities. Henceforth, numerous investors assess their speculationoccasion with the assistance of various techniques to minimize their risk throughsuitablepronouncement. In the assessment of investment opening for investors use to measuretheir risk and returnsconnectedby it. Investors usuallyobserver ups and downs on indices to recognize the performance of the stock market.

The stock market grabs a vital domicile in Indian economy. The Bombay Stock Exchange (BSE) is one of the primogenital exchanges in India and World as well in terms of superiority and advancement of technology.Banking sector played a vital role in Indian economy and banking stocks are the most important part of Bombay Stock Exchange (BSE). This study takes into consider the daily closing prices of four majorbanking stocks of BSE 30 (HDFC Bank, ICICI Bank, AXIS Bank and SBI) to analyze the risk and returns of the selected stocks. To examine the performance of these stocks, daily closing prices taken into consideration to analyze the risk return a period of fifteen years from $1^{\text {st }}$ January, 2001 to $31^{\text {st }}$ December, 2015. 


\section{LITERATURE REVIEW}

Riskreturn trade-off is the significant deciding factor. Beta and several statistical models also used to test the association between the risk and return. Bhunia (2012) measured the Capital asset pricing model as measurement tool and established that there is no competencedemonstrated in Indian market. Ratna (2013) examined the performance of IT stocks with banking stocks and the different statistical tools used for examining the hypothesis with descriptive analysis and t-test, suggested to hold stocks to accomplish the optimisticconsequences.

Setiawan et.al, (2013) analysed the performance of Syariah stocks with orthodoxy stocks listed on Indonesia This study used Risk-Adjusted Return dimensions. They originated that there is no significant difference on risk and returns, measured by weekly return, standard deviation and beta, between both Syariah and orthodoxy stocks. Additionally, they also appraised the performance of both Syariah and orthodoxy stocks portfolio.Ansar et.al (2014),established "A-Y Model" to find out the performancesthroughrisk and return of the portfolio and investigate during the bullish and the bearish market. The consequences of the model designates that there is no reliable performance exist between the portfolio expected return and board risk.

Sharma et.al, (2012) scrutinizes the risk return trade off of the stocks listed in the stock exchanges of South Asia. This study aimed to find out, the expected return and risk connected over time by using the descriptive statistics. The studyfound that high returns and rational risk complicated in those South Asian countries. Shanmugasundram, G. and Benedict, D. John (2013) deliberate risk influenced in the Indian Sectoral indices and Nifty. They found risk association in varied with time period. They had designated five Sectoral indices from NSE and Nifty Index for 8 years from 2004 to 2012. For the study t-Test and ANOVA carried out to find out the risk alteration between the sectors and Nifty.

P. Swarna Lakshmi, (2013) analysed the volatility pattern in different Sectoral Indices in Indian stock market utilising Autoregressive Conditional Heteroskedasticity, an econometric model. This study was conducted for the period starting 2008 till 2012 of eleven Sectoral Indices from NSE. Researcher determined the reality sector has uppermost volatility than other sector, however the banking sector has bottommost volatility for the period.The risk and return connection in Latin American, Brazilian, and Columbian equity markets for which quarterly data were measured over the period (Tsuji, 2014).

\section{OBJECTIVES OF THE STUDY}

The objectives of this study are to capture the risk return analysis of sample banking stock. The aim is to help the investors (current and potential) understand the risk return trade off of banking stock at Bombay stock market. The objectives of the study are

1. To examine the relationship between risk \&returns ofSensex and Banking stocks.

2. To analyzethe constancy of beta for fourBanking stocks of BSE Sensex with respect to Sensex.

\section{HYPOTHESIS OF THE STUDY}

Keeping the objectives in view, the hypothesis framed for the study is H0: There is no significant relationship between Sensex returns and banking stock returns Ha: There is a significant relationship between Sensex returns and banking stock returns

\section{METHODOLOGY AND TESTS USED IN THE STUDY}

In this study different BSE Sensex and banking stock indices have been used to examine the risk return trade off of BSE Sensex with that of HDFC Bank, ICICI Bank, Axis Bank and SBI. The risks and returns have been examined by using the daily closing value of BSE Sensex and four banking stocks. The risk and return centered on Sensex have taken into consideration of the measurement of market returns and market risk, correspondingly. BSE Sensex characterizes the foremost market capitalization on BSE.The 
study is based on secondary data. The data for the analysis has taken from the BSE website over a period of 15 years from January 1, 2001 to December 31, 2015.

\section{Methods of Investigation}

The main objective of the study is to comprehend the risk-return accompanying with BSE and other sample banking stocksas well as to construct a linear regression model keeping BSE Sensex index as dependent variable and other banking stock indices as independent variable. In this analysis for testing the presence or absence of risk return trade off in the Indian equity markets and for testing hypothesis, different methods like correlation, regression, descriptive statistics and t test have been adopted.

The Daily index returns of the stock markets have been computed using the following formula; The return has been calculated on the basis of the model:

$$
\begin{aligned}
& \mathrm{rt}=\ln (\mathrm{It} / \mathrm{It}-1) \\
& \text { Where } \\
& \mathrm{rt} \quad=\text { Return on stock price } \\
& \mathrm{ln} \quad=\text { Natural logarithm } \\
& \mathrm{It} \quad=\text { the closing index } \\
& \mathrm{It}-1 \quad=\text { the closing index }
\end{aligned}
$$

The standard deviation of all indices designed from the underneath mentioned formula to compute the risk associate with the return of indices.

$$
\begin{aligned}
& \sigma=\sqrt{ }(((\mathrm{x} 1-\mu) 2+(\mathrm{x} 2-\mu) 2+. .+(\mathrm{xn}-\mu) 2) / \mathrm{n}) \\
& \text { Where } \mu=(\mathrm{x} 1+\mathrm{x} 2+. .+\mathrm{xn}) / \mathrm{n}(1)
\end{aligned}
$$

Descriptive Statistics is anestablished of momentary descriptive coefficients that summariesaassumed set of data, that can also be a demo of the whole population. Descriptive statistics are being uses to survey the central tendency (position) of data.

Correlationfind out the linear relationshipamong two variables is measured by the correlation coefficient. In assumed set of explanations $(\mathrm{x} 1, \mathrm{y} 1),(\mathrm{x} 2, \mathrm{y} 2), \ldots(\mathrm{xn}, \mathrm{yn})$, can be derived by computing the correlation coefficient(r)

$$
r=\frac{1}{n-1} \Sigma\left(\frac{x-\bar{x}}{s_{x}}\right)\left(\frac{y-\bar{y}}{s_{y}}\right)
$$

Beta $(\beta)$ measures the market risk or systematic risk. Beta is commonlycomputed by the under given formula.

$\beta=(\operatorname{Cov}(\mathrm{ra}, \mathrm{rm})) /(\operatorname{Var}(\mathrm{rm}))$

Wherera is the return of an indexand $\mathrm{rm}$ is benchmark index return.

To predict the performance of BSE Sensex with the help of banking stock data linear relationship was presumed keeping Sensex as dependent variable and return of other securities as independent variable. The formula used is given below

$$
\mathrm{R}=\mathrm{a}+\Sigma(\mathrm{i}=1) \mathrm{n} \text { 【biRi } \rrbracket
$$

Where $\mathrm{R}=$ Return of Sensex Index

$\mathrm{a}=$ constant,

$\mathrm{Ri}=$ Return of banking stock indices

bi is the coefficient of particular banking stock index.

The paired t-test decides whether the difference from between two sample is significant or notunderneath the expectations that the paired differences are independent and identically normally distributed.

To put on the test, let 


$$
\begin{aligned}
& \hat{X}_{i}=\left(X_{i}-\bar{X}\right) \\
& \hat{Y}_{i}=\left(Y_{i}-\bar{Y}\right)
\end{aligned}
$$

Formerlydemarcated by

$$
. t=(\bar{X}-\bar{Y}) \sqrt{\frac{n(n-1)}{\sum_{i=1}^{n}\left(\hat{X}_{i}-\hat{Y}_{i}\right)^{2}}}
$$

Here statistic has (n-1) degrees of freedom.

The P value (premeditated probability) is the projected probability of discarding the null hypothesis of a study at what time that hypothesis is correct. Null hypothesis is frequently a hypothesis of "no differences" besidespractice to explainobviouslybeforehand the beginning of the study. When the P value is a smaller total than the selected significance level then itdiscard the null hypothesis i.e. agree to accept that sample gives sensibleindication to provision the substitute hypothesis. On this point in this study the level of significant has been taken as $5 \%$ confidence level.

\section{DATA ANALYSIS AND INTERPRETATION}

\section{Comparative Analysis of Risks and Returns of Different Stock Returns}

Table-1 summarizes the statistical results of daily stock market returns of different stock indices from January 2001 to December 2015 by the help of descriptive statistics.

Table-1

Descriptive Statistics of the Returns

\begin{tabular}{|l|c|c|c|c|c|}
\hline \multicolumn{1}{|c|}{ Particulars } & SENSEX & HDFC & ICICI & AXIS & SBI \\
\hline Mean & 0.0505 & 0.0420 & 0.0151 & 0.0612 & 0.0037 \\
\hline Standard Deviation & 1.4994 & 3.3206 & 3.7998 & 3.9219 & 4.3973 \\
\hline Kurtosis & 8.0825 & 1454.5359 & 840.7088 & 767.9197 & 1938.1517 \\
\hline Skewness & -0.1366 & -30.0456 & -19.9302 & -18.5088 & -37.3454 \\
\hline Range & 27.7992 & 182.2855 & 180.7594 & 179.8395 & 246.6704 \\
\hline Minimum & -11.8092 & -160.3947 & -160.0471 & -161.3146 & -228.2321 \\
\hline Maximum & 15.9900 & 21.8908 & 20.7122 & 18.5249 & 18.4383 \\
\hline
\end{tabular}

It has observed from above during the study period i.e. from January 2001 to December 2015, all indices showed positive average daily returns. The average daily returns recorded highest of 0.0612 in case of AXISBank, whereas it found lowest of 0.0037 in the case of SBI. The average daily return of Sensex is found to be 0.0505 , which is more as compare to HDFCBank, ICICIBank and SBI, while Sensex average return is less than that of AXISBank. Therefore from the above clearly suggest that average daily return of Sensex is higher than that of all Banking stock returns except AXISBank over the study period. On the contrary, the standard deviation of Sensex islowermostassociate to all Banking stock returns. The standard deviation of SBI stock return isuppermost for the mention period. Thereforeit indicates thatSBI stockencompasses maximum risk than that of all other stock returns, while Sensex return comprises minimum risk. The daily returns distribution of all sample stock returns are found to be negatively skewed. All stock returns are observed to be leptokurtic (peaked) by nature i.e. it is lowest in case of Sensex and more peaked in case of SBI. 


\section{Correlation between BSE Sensex and Banking Stock Returns}

The Table-2 elaborates the correlation matrix for daily stock returns of Sensex and Banking stock over a span of fifteen years from January 2001 to December 2015.

Table-2

Correlation of Daily Stock Market Returns

\begin{tabular}{|l|c|c|c|c|c|}
\hline Particulars & SENSEX & HDFC & ICICI & AXIS & SBI \\
\hline SENSEX & 1.0000 & & & & \\
\hline HDFC & 0.0248 & 1.0000 & & & \\
\hline ICICI & -0.0108 & -0.0046 & 1.0000 & & \\
\hline AXIS & 0.0842 & 0.0008 & 0.0051 & 1.0000 & \\
\hline SBI & 0.0125 & -0.0058 & 0.0014 & 0.0266 & 1.0000 \\
\hline
\end{tabular}

From the Table, it can observe that daily stock market returns of Sensex are positively correlated with that of all Banking stock returns except that of ICICI Bank (negatively correlated). The Sensex returns is highly correlated with that of AXIS Bank, where as it has recorded negative correlation with that of ICICI Bank.

\section{Analysis of Beta with Reference to Sensex}

Beta (market risk) of all sample bankingstockswith reference to Sensex found out as discussed below.

Table-3

Beta Coefficient of Daily Stock Market Returns

\begin{tabular}{|l|c|c|c|c|}
\hline Particulars & HDFC & ICICI & AXIS & SBI \\
\hline Beta & 0.0112 & -0.0043 & 0.0322 & 0.0043 \\
\hline Rank & 3 & 1 & 4 & 2 \\
\hline
\end{tabular}

The above table displays that ICICIBank is greatest defensive stock i.e. it is negatively sensitive to variationshappening to Sensex. However AXIS bank is greatest sensitive stock, its' return existence 0.0322 which specifies $1 \%$ variation in Sensex will give $0.0322 \%$ change in AXIS Bank return, and formerly next to it are HDFC Bank and SBI.

\section{Analysis Return per Volatility}

Table 4 demonstrations the ranking of banking stock returns according to return per volatility measured in terms of beta. HDFC Bank stock return ranks higher as compare to other in the case of return per volatility and ICICI Bank stock return has positioned at backseat, which designates that if investors have to selectamongdifferent stocks then HDFCBank has performed better than that of other stocks throughout the study period.

Table-4

Return per Volatility Daily Stock Market Returns

\begin{tabular}{|l|c|c|c|c|}
\hline Particulars & HDFC & ICICI & AXIS & SBI \\
\hline Return/Beta & 3.7515 & -3.5478 & 1.8992 & 0.8602 \\
\hline Rank & 1 & 4 & 2 & 3 \\
\hline
\end{tabular}

\section{Analysis Return per Standard Deviation}

Table 5 indicates the position of different banking stocks' returns with the relation to standard deviation. Here it can observe thatAXISBank has performed better (less risky), than other banksthroughout the study 
period, whereas SBI bank has to improve in the measure of return per standard deviation for reducing the risk.

Table-5

Return per Standard Deviation Daily Stock Market Returns

\begin{tabular}{|l|c|c|c|c|}
\hline \multicolumn{1}{|c|}{ Particulars } & HDFC & ICICI & AXIS & SBI \\
\hline Return/Standard Deviation & 0.0127 & 0.0040 & 0.0156 & 0.0008 \\
\hline Rank & 2 & 3 & 1 & 4 \\
\hline
\end{tabular}

Analysis of Significance Test Results of Different Stock Markets

Table-6 shows the t-statistics Significance results and P-Value of daily returns for different stock returs for the study period from January 2001 to December 2015.

Table-6

Significance Test Results of Comparisons of Different Stock Index

\begin{tabular}{|l|c|c|c|c|}
\hline Particulars & HDFC & ICICI & AXIS & SBI \\
\hline t Stat & 0.1377 & 0.5392 & -0.1591 & 0.6311 \\
\hline P Value & 0.4452 & 0.2949 & 0.4368 & 0.2640 \\
\hline
\end{tabular}

The $\mathrm{P}$ value of $0.4452,0.2949,0.4368$ and 0.2640 respectively of four banking stock returns i.e, HDFCBank, ICICIBank, AXISBank and SBI indicate, there is no significant difference between daily returns of Sensex and other sample stock returns at 5\% degree of significance. Therefore the null hypothesis (there is no significant relationship between Sensex returns and banking stock returns) is accepted

Regression Results for Returns on Sensex Dependent Variable and Various Stock Returns as Predictors

Table 7

Regression Results for Sensexas Dependent Variable and Various Factors as Predictors

a) Model Summary

\begin{tabular}{|c|c|c|c|}
\hline Multiple R & R Square & Adjusted R Square & Standard Error \\
\hline 0.0891 & 0.0079 & 0.0069 & 1.4944 \\
\hline
\end{tabular}

b) Goodness of Fit - ANOVA

\begin{tabular}{|l|c|c|c|c|}
\hline Particulars & SS & MS & F & Significance F \\
\hline Regression & 66.6217 & 16.6554 & 7.4578 & 0.0000 \\
\hline Residual & 8332.4596 & 2.2333 & & \\
\hline Total & 8399.0814 & & & \\
\hline
\end{tabular}

c) Regression Coefficients

\begin{tabular}{|l|c|c|c|c|}
\hline Particulars & Coefficients & Standard Error & $\mathrm{t}$ Stat & P-value \\
\hline Constant & 0.0480 & 0.0245 & 1.9623 & 0.0498 \\
\hline HDFC & 0.0111 & 0.0074 & 1.5132 & 0.1303 \\
\hline ICICI & -0.0044 & 0.0064 & -0.6797 & 0.4967 \\
\hline AXIS & 0.0321 & 0.0062 & 5.1482 & 0.0000 \\
\hline SBI & 0.0035 & 0.0056 & 0.6375 & 0.5239 \\
\hline
\end{tabular}




\section{a. Dependent Variable: Sensex}

The above table'si.e, 7 (a), (b) and (c) derivedthe regression analysis between Sensex returns as dependent variable with the banking returns as independent variables. The goodness of fit consequences of standard linear multiple regressions throughSensex as the dependent variable and numerousdeterminants as forecasters are described in Table 7(a) and themodelresulthas elaborated in Table 7 (b). The F-statistics value of $7.4578(\mathrm{P}<0.01)$ show that the independent variables are jointly statistically significant at $1 \%$ level. This model discloses that statistically insignificant association among Sensex and all banking stock returns (Sig.> 0.05) except that of AXIS Bank. The regression result in table 7 (c) indicates that the coefficient for AXIS bank is 0.0321 and is statistically significant at 1 per cent level, with p-value of 0.0000 . The model coefficients have revealed in Table 7(c) and the outcomes designate that no one of the indicators of Sensex are significant ( $p>0.05$ in all cases) except AXIS Bank. This study indicates that, the association among Sensex returns and banking stock returns by suggesting that there are statistically insignificant associations among Sensex returns and on the banking stock returns except that of AXIS Bank.

\section{CONCLUSION}

In this study, the Sensex returns and Banking stock returns have been used to find out the comparative risk return analysis between Sensex returns with that of sample banking stock returns. More specifically, to examine the correlation four major Banking stock market indexes \& returns, (the HDFC Bank, the ICICI Bank, the AXIS Bank and the SBI), with BSE Sensex index return, during the period January 2001 to December 2015. Results obtained from the correlation analysis reveals that Sensex returns is high correlation withAXIS Bank returns and negative correlation between ICICI Bank returns. On the other hand, from descriptive analysis it can found thatSensex returns as well as all the stock returns positive average daily returns except ICICI Bank return for the selected period.The Sensex generated high returns, as compared to all other stock apart from AXIS Bank return.SBI return shows the highest volatility during the period whereas; it is lowest in Sensex return. In the case of $t$ test and the p-value, it can conclude that returns of different stockreturnsthat there is no significant difference between and banking stock returns. It is clear from the above that the Null Hypothesis $\left(\mathrm{H}_{0}\right)$, there is no significant difference between returns of Sensex andbanking stock returns is accepted.In the case of market risk ICICI bank is greatest defensive stock, whereas AXIS Bank is greatest sensitive stock, which highly varies with Sensex return. All the banking stocks change in similar trend of Sensex since the values of beta are positive except ICICI Bank, which has negative beta. The regression analysis study indicates that, the association among Sensex returns and banking stock returns by suggesting that statistically insignificant associations among Sensex returns and on the banking stock returns except that of AXIS Bank.

\section{REFERENCES}

1. Srivastava, "Stability of sector wise beta: Case study of India," GFJMR, vol. 5, pp. 1-9, 2012.

2. AmalenduBhunia (2012). Stock market efficiency in India: Evidence from NSE. Universal Journal of Marketing and Business Research Vol. 1(2), 072-78.

3. Ansar Mahmood et.al, (2014). A risk-return based model to measure the performance of portfolio management. Management Science Letters, 4.

4. Chandra Setiawan (2013). Syariah and Conventional Stocks Performance of Public Companies Listed on Indonesia Stock Exchange. Journal of Accounting, Finance and Economics, 3(1), 51 64.

5. Chikashi Tsuji (2014). An Investigation of the Relationship between Risk and Return: The Case of the Latin American Stock Markets. Accounting and Finance Research, 3(1). 
6. D. Cao, W. Long, and W. Yang, "Sector indices correlation analysis in China's stock market," in Proc. International Conference on Information Technology and Quantitative Management, Procedia Computer Science, 2013, pp. 1241-1249.

7. Debjiban Mukherjee (2007).Comparative Analysis of Indian Stock Market with International Markets, Great Lakes Herald, 1(1).

8. Donald. B Keim (1983). Size Related Anomalies and Stock Return Seasonality. Journal of Financial Economics, 12, 13-32.

9. Fischer Black and John C. Cox (1976).Valuing Corporate Securities: Some Effects Of Bond Indenture Provisions, The Journal of Finance, 31(2), 351-367.

10. G. Shanmugasundram and D. J. Benedict, "Volatility of the Indian sectoral indices-A study with reference to national stock exchange," International Journal of Marketing, Financial Services \& Management Research, vol. 2, no. 8, pp. 1-11, 2013.

11. Gagan Deep Sharma et.al, (2012). Rewards and Risks in Stock Markets: A Case of South Asia. The International Journal of Applied Economics and Finance, 6(2), 37-52.

12. M. Rawashdeh and J. Squalli, "A sectoral efficiency analysis of the Amman stock exchange," Working Paper No. 05-04, Economic Policy Research Unit, 2005.

13. P. S. Lakshmi, "Volatility patterns in various sectoral indices in Indian stock market," Global Journal of Management and Business Studies, vol. 3, no. 8, pp. 879-886, 2013.

14. P. V. V. Kumar and P. K. Singh, "A study of return, liquidity of sectoral indices, market index return of Indian financial market (BSE)," International Journal of Research in Commerce \& Management, vol. 2, no. 6, pp. 1-8, 2011.

15. R. Gupta and P. K. Basu, "Weak form efficiency in Indian stock markets," International Business \& Economics Research Journal, vol. 6, no. 3, pp. 57-64, 2007.

16. R. Krishnankutty and A. K. Tiwari, "Are the Bombay stock exchange sectoral Indices of indian stock market cointegrated? Evidence using fractional cointegration test," MPRA Paper No 48590, Journal of Emerging Financial Markets, vol. 2, no. 1, pp. 37-45, 2011.

17. Ratna Sinha (2013). An Analysis of Risk and Return in Equity Investment in Banking Sector. International Journal of Current Research, 5(8), 2336-2338.

18. S. Mohandass and P. Renukadevi, "Modeling volatility of BSE sectoral indices," International Journal of Marketing, Financial Services \& Management Research, vol. 2, no. 3, pp. 12-24, 2013.

19. S. Rajamohan and M. Muthukamu, "Bank nifty index and other sectoral indices of NSE-A comparative study," PARIPEX-Indian Journal of Research, vol. 3, no. 4, pp. 147-149, 2014.

20. Thomas Barnes (2013).The IT Industry and Economic Development in India: A Critical Study. Journal of South Asian Development, 8(1), 61-83. 